\title{
MEMETAKAN ANATOMI DISKURSUS ISLAMISME DAN TERORISME ISLAM
}

\author{
Ridwan Rosdiawan \\ Institut Agama Islam Negeri Pontianak, Indonesia \\ E-mail: rrosdiawan@gmail.com
}

\begin{abstract}
What is the main factor of terrorism; Islamic doctrine, or political factor? There are three mainstream opinions provide theoretical reviews. Firstly, those who believe that the justification of acts of violence to terrorism is an inherent product of religious doctrine. Secondly, those who consider that terrorism is a profane matter have absolutely nothing to do with religion. Thirdly, the opinion which states that terrorism is syncretism and interrelative modification between politics and religion. This article tries to examine the three views above by dissecting other perspectives in order to get a clearer picture about the discourse of Islamism transforming into a radical movement leading to terrorism. Doctrinal and political motives are so strongly integrated and overlapping in the structure of the motives and actions of these radical groups. Departing from the view that Islamism is a movement that aims to make radicalrevolutionary changes in social structure institutions, this article collects theories that can be used as maps to understand the construction of Islamism.
\end{abstract}

Keywords: Islamism; religious terrorism; doctrine; politics.

\section{Pendahuluan}

Pengidentikan Islam dengan terorisme kembali mendominasi perbincangan publik global dalam interval 2015-2017 setelah hampir satu windu sebelumnya sempat mereda. ${ }^{1}$ Kemunculan

\footnotetext{
1 "Terorisme Islam" mengemuka sebagai diskursus utama geopolitik dan stabilitas keamanan global semenjak terjadinya peristiwa terorisme terbesar yang menimpa Amerika Serikat (AS) pada 11 September 2001. Respons AS dengan menggaungkan kampanye Global War against Terror dan Bush Doctrine yang melegalkan aksi agresif pendekatan militer menyasar target-target utama para
} 
kembali diskursus Islam sebagai antitesis dari stabilitas keamanan dunia memang tidak terlepas dari dinamika wacana politis oleh penentu kebijakan global seperti platform politik presiden Amerika Serikat (AS), disebabkan eskalasi kejadian-kejadian kekerasan di beberapa wilayah yang sebelumnya jarang tersentuh oleh kasus terorisme.

Intensitas perhatian masyarakat dunia terhadap wacana yang berakar dari tesis Clash of Civilization-nya Huntingtonian tersebut mengalami pasang surut. Sejak peristiwa terorisme terbesar yang pernah menghantam AS pada 11 September 2001, yang menjadi sasaran kebijakan aksi counter-terror di dua masa pemerintahan George W. Bush Jr. (2001-2008), entitas konseptual "terorisme Islam" pernah mereda pada periode Barack H. Obama yang cenderung mengidentifikasi kekerasan teror sebagai murni tindakan politis. Meski peristiwa terorisme berlatar belakang agama banyak terjadi pada masa pemerintahannya, Obama selalu berusaha memandang peristiwa itu sebagai dinamika politik regional dan mengeksklusikannya dari inspirasi agama secara umum. Asumsi Islam sebagai agama inspirator terorisme kemudian menguat kembali ketika Donald Trump memenangkan suksesi kursi kepresidenan AS.

Dalam pidato politik resmi pertama yang disampaikan saat pelantikannya sebagai presiden AS, Trump menyatakan bahwa salah satu musuh global utamanya adalah radical Islamic terrorism, dan ia mengajak seluruh kekuatan dunia untuk bersatu memerangi musuh tersebut. Implikasinya, Trump sama sekali tidak menganut pembedaan terhadap elemen keberagaman dalam masyarakat Muslim. Ia memandang bahwa bagaimanapun bentuknya Islam berpotensi untuk diradikalisasi dan menjelma menjadi potensi teror. Islamophobia kemudian menempati posisi sentral dalam

teroris dan pihak yang melindunginya. Dalam praktiknya, target-target dari aksi militer yang dipimpin AS tersebut, sebagaian adalah elemen dari komunitas Muslim dunia sehingga kesan bahwa terorisme terkait erat dengan Islam semakin kuat. Kesan ini sempat surut ketika kursi kepresidenan AS berpindah dari George W. Bush ke Barack H. Obama yang berhasil mengeliminasi tokoh ikonik terorisme transnasional Osama bin Laden pada Mei 2011. Untuk penjelasan lebih lanjut, baca Ridwan Rosdiawan dan Dwi Surya Atmaja, Islamic Terrorism: The Ambiguity between Accusation and Justification (Pontianak: IAIN Pontianak Press, 2016). 
kebijakan pemerintahan Trump, ${ }^{2}$ dan indikasi tersebut semakin kuat ketika ia mengeluarkan Executive Order perdananya yang melarang warga dari tujuh negara mayoritas Muslim untuk masuk ke AS atas dasar kekhawatiran potensi terorisme. ${ }^{3}$

Potensi Islamophobia versi pemerintahan Trump tersebut selanjutnya seakan mendapatkan konfirmasi faktual seiring meningkatnya frekuensi peristiwa kekerasan dan perang di berbagai belahan penjuru dunia Muslim. Terus berkobarnya konflik politik sektarian di Syria, Irak, Yaman, dan Afghanistan telah menjadi kekhawatiran utama stabilitas dan masalah kemanusiaan dunia. Bukan hanya jumlah korban yang terus mengalami peningkatan, tetapi juga intensitas terorisme yang skala cakupan teritorialnya terus meluas dengan metode dan peralatan aksi yang semakin bervariasi. Sebuah laporan yang dirilis oleh The Institute of Economics and Peace bertajuk Global Terrorism Index, yang menyisir indeks keamanan teritorial global dengan sample 163 negara atau $99.7 \%$ dari keseluruhan populasi dunia, menyebutkan bahwa lebih dari $50 \%$ peristiwa terorisme di dunia terjadi di dunia Islam, dengan pelaku serta korban yang juga mayoritas adalah Muslim. ${ }^{4}$

Laporan yang merangkum lebih dari 150.000 peristiwa terorisme yang terjadi di seluruh dunia sejak 2000-2016 juga menyebutkan bahwa peningkatan kekerasan teror menjadi berlipat sejak 2010 dan sangat terkait erat dengan fenomena Arab Spring yang mengguncang stabilitas keamanan wilayah Timur Tengah. Efek migrasi yang timbul dari konflik tersebut juga berimbas kepada ekspor kekerasan ke wilayah-wilayah Barat, khususnya Eropa, yang kemudian menderita serangan terorisme terbesar

\footnotetext{
2 John Feffer, “Trump v. Islam”, Foreign Policy in Focus, 21 February 2017.

3 Executive Order (EO) adalah sebuah instruksi prerogratif presiden dalam konteks politik domestik AS yang berimplikasi kebijakan langsung. EO pertama Presiden Donald J. Trump ini dirilis pada 27 Januari 2017, dan tujuh negara yang menjadi obyek penangguhan visa masuk negara AS itu adalah Iran, Irak, Somalia, Libya, Sudan, Syria, dan Yaman. Lihat The White House Office of Presidential Secretary, "Executive Order: Protecting the Nation from Foreign Terrorist Entry into the United States", The White House, 27 Januari 2017.

${ }^{4}$ Meski dikritik karena mengandung beberapa kekeliruan detail dalam deskripsi latar belakang kelompok-kelompok teroris, dokumen laporan ini telah mendapatkan banyak perhatian baik dari kalangan pemangku jabatan maupun akademisi, serta menjadikannya sebagai referensi kebijakan maupun review akademis. Lihat Institute for Economics and Peace, Global Terrorism Index 2016 (Maryland: University of Maryland, 2016).
} 
untuk pertama kalinya sejak 2000. Prancis, Belgia, serta Turki disebut-sebut sebagai negara yang paling banyak dilanda kejadian terorisme. Bahkan belum genap waktu empat bulan di awal 2017 ini, terorisme dalam skala besar secara berturut-turut telah menghantam Istanbul, Berlin, London, St. Petersburg, serta Stockholm yang sebelumnya terkenal sebagai tempat teraman dan belum pernah mengalami peristiwa kekerasan yang signifikan. Pihak yang teridentifikasi sebagai pelaku dari serangkaian aksi mengerikan di atas selalu mengerucut ke dua nominasi tersangka, ISIS (the Islamic State of Iraq and Syria) dan Al Qaeda. ${ }^{5}$

ISIS dan Al Qaeda adalah dua organisasi yang sarat dengan simbolisme Islam. Kata "Islamic State" yang melekat pada namanya serta 'bendera Muhammad' berwarna hitam dengan tulisan putih secara eksplisit memproklamasikan identitasnya, sehingga banyak yang merasa tak perlu menggali jauh seputar doktrin yang mereka anut untuk menjustifikasi bahwa ISIS adalah representasi nyata dari ideologi Islam. Sementara itu, Al Qaeda merupakan organisasi yang lekat dengan sosok Osama bin Laden. Selain sebagai figur utama dan pendiri organisasi ini, Bin Laden kerap dideskripsikan sebagai seorang 'pembela Islam dan Muslim' di seluruh dunia yang rela meninggalkan gelimang kenyamanan kehidupan dunia dan tinggal di dalam gua untuk berperang demi kejayaan Islam dan penganutnya. Fatwa-fatwa yang ia keluarkan umumnya berisi ajakan bagi seluruh Muslim untuk bangkit melakukan perlawanan dan peperangan terhadap kekuatan Barat yang ia anggap telah menghancurkan dan membantai Muslim di mana-mana, khususnya di Palestina, Irak, dan Afghanistan. Bahkan setelah kematiannya pada Mei 2011, figur Bin Laden terus menginspirasi organisasinya untuk tetap eksis dan mengeksekusi perlawanan dalam bentuk kekerasan. Aksi-aksi yang dilakukan baik oleh ISIS maupun $\mathrm{Al}$ Qaeda umumnya terekspos oleh media mainstream sebagai sebuah bentuk kekerasan dengan segala efek psikologisnya. Akibatnya, munculnya gambaran dalam persepsi audiens global bahwa aksi terorisme yang mereka lakukan sangat terkait dengan ideologi yang mereka anut tidak dapat dihindarkan.

5 Christina Anderson, "Stockholm Truck Attack Kills 4; Terrorism is Suspected", The New York Times, 7 April 2017; dan Lizzie Dearden, "Sweden Terror Attack", Independent, 7 April 2017. 
Menurut data yang dimiliki oleh Global Terrorism Database (GTD), University of Maryland, ISIS dan Al Qaeda tidak sendirian dalam memonopoli ranking teratas daftar eksekutor peristiwa terorisme dengan intensitas kejadian dan korban terbanyak di dunia. Dalam laporan tahun 2015, GTD mencatat bahwa kejadian terorisme internasional yang terjadi dalam kurun waktu tersebut dan memakan banyak korban jiwa mayoritas terjadi di negaranegara Muslim khususnya di wilayah Irak, Syria, Nigeria, Yaman, dan Afghanistan. Pelaku yang paling bertanggung jawab terhadap kejadian tersebut, menurut Erin Miller, Direktur National Consortium for the Study of Terrorism and Responses to Terrorism, hanyalah sebagian kelompok saja, yaitu ISIS, Al Qaeda, Taliban, dan Boko Haram. Aksi-aksi terorisme yang dikaitkan dengan kelompok-kelompok tersebut bahkan mendominasi urutan teratas dalam daftar peristiwa teror paling mematikan tahun 2015, sebagaimana tampak dalam tabel di bawah ini: ${ }^{6}$

Tabel 1:

Serangan Teror Paling Dahsyat Tahun 2015

\begin{tabular}{|c|c|c|c|c|}
\hline PANIK. & OATE & LOCATION & Grour REsRONSBRLE & $\begin{array}{l}\text { NUMBER } \\
\text { KLLLED }\end{array}$ \\
\hline 1 & $4 / 9 / 15$ & Gaim, irag & Ealamic Stats & 100 \\
\hline 2 & $5 / 21 / 15$ & Paimyra, Sycia & Islemic State & 280 \\
\hline 3 & $9 / 2 \mathrm{~B} / 15$ & Kunduz, Afghanistan & Taliban & $24:$ \\
\hline 4 & $4 / 25 / 15$ & Karsmoa Noger & Boko Haram & 230 \\
\hline$=$ & 10/31/15 & Unbrown, Eqyat & $\begin{array}{l}\text { Sinat Prowince of the islamic } \\
\text { State }\end{array}$ & 224 \\
\hline 6 & $4 / 23 / 10$ & Ishtabraq, Syna & Ansar al-Din Front & 200 \\
\hline 7 & $6 / 25 / 15$ & Kobani, Syna & Lalome State & 174 \\
\hline 8 & $8 / 13 / 15$ & $\begin{array}{l}\text { Kukuwa-Gani, } \\
\text { Nigena }\end{array}$ & Boka Haram & 174 \\
\hline 2 & $4 / 2 / 15$ & Gansas, Kanya & Al-Shohanb & 152 \\
\hline 10 & $1 / 12 / 15$ & Kalofata, Camaroon & Boko Haram & 144 \\
\hline 10 & $2 / 4 / 15$ & Fotobd, Camemon & Boko Haram & 146 \\
\hline 12 & $8 / 1 D / 15$ & $\begin{array}{l}\text { Starchnativika } \\
\text { Uisaine }\end{array}$ & Donetsk Pleapls's Pepubic & 143 \\
\hline 13 & $1 / 29 / 15$ & Fotoikd, Camenon & Boka Haram & 126 \\
\hline 14 & $7 / 17 / 15$ & Eani Saad, Iraq & Ealsme State & $12:$ \\
\hline is & $10 / 7 / 15$ & Gonir, Nigeria & Goko Haram & 108 \\
\hline 16 & $1 / 13 / 15$ & Unknown, Nigena & Boko Haram & 107 \\
\hline v & $10 / 10 / 75$ & Ankara, Turkey & Islamk Statn & 105 \\
\hline 18 & $2 / 1 / 15$ & Tungushe, Nigena & Eoko Haram & $10 t$ \\
\hline$m$ & $10 / 12 / 75$ & Ghazn, Afqhanistan & Taliban & 100 \\
\hline 20 & 7//Vis & Kukawa, Nigena & Eoko Haram & 97 \\
\hline 21 & $9 / 1 / 15$ & Janale, Samals & Al-Shubanb & 25 \\
\hline 22 & $3 / 75 / 15$ & Egba, Nigena & Fuluni Mlitants & 95 \\
\hline 23 & $11 / 13 / 15$ & Paris, France & Islamic State & 92 \\
\hline 24 & $2 / 16 / 15$ & $\begin{array}{l}\text { Wazs dstrict, } \\
\text { Cameronn }\end{array}$ & Eoko Haram & 9: \\
\hline 25 & $5 / 6 / 15$ & Aden, Yomen & Hutha & 85 \\
\hline
\end{tabular}

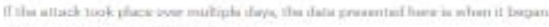

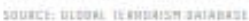

${ }^{6}$ Erin Miller et al., Global Terrorism Database 2015 (Maryland: START, 2016), ivvii. 
Tabel 2:

Kelompok Teroris Paling Berbahaya Tahun 2015

\begin{tabular}{clr} 
RANK & GROUP/AFFILIATION & FATALITIES \\
\hline $\mathbf{1}$ & Islamic State & 8420 \\
\hline $\mathbf{2}$ & Boko Haram & 6299 \\
\hline $\mathbf{3}$ & Taliban & 5215 \\
\hline $\mathbf{4}$ & Al-Shabaab & 1586 \\
\hline $\mathbf{5}$ & Huthi Extremists & 1306 \\
\hline $\mathbf{6}$ & Al-Nusrah Front & $\mathbf{9 2 4}$ \\
\hline $\mathbf{7}$ & $\begin{array}{l}\text { Sinai Province of the } \\
\text { Islamic State }\end{array}$ & 604 \\
\hline $\mathbf{8}$ & Donetsk People's Republic & 597 \\
\hline $\mathbf{9}$ & Fulani Militants & 572 \\
\hline $\mathbf{1 0}$ & $\begin{array}{l}\text { Tehrik-i-Taliban Pakistan } \\
\text { (TTP) }\end{array}$ & $\mathbf{3 6 8}$ \\
& &
\end{tabular}

Excludes attacks where group is unknown.

SOURCE: GLOBAL TERRORISM DATABASE

Meski peran kelompok-kelompok garis keras di atas dalam peristiwa terorisme tahun 2015 tampak begitu mencolok, fakta tersebut sebetulnya masih terbilang kecil jika dibandingkan dengan sepak terjang mereka di 2014. Kelompok-kelompok tersebut bertanggung jawab terhadap lebih dari 17.000 serangan dengan korban mencapai lebih dari 43.000 jiwa pada 2014. Angka ini jauh sedikit melebihi dari catatan tahun 2015 yang berkisar di angka 15.000 kejadian dan 38.000 korban jiwa. ${ }^{7}$ Pada 2014 ini juga jumlah dari kelompok militan Islam dan jihadis bertambah sekitar $58 \%$ dan hampir dua kali lipat lebih banyak dibanding data $2010 .{ }^{8}$ Berdasarkan data angka dan fakta tersebut banyak yang menyimpulkan bahwa tren terorisme mutakhir sangat terkait dengan simbol-simbol religius khususnya Islam. Secara doktrinal, Islam dituding telah menjadi inspirasi utama di balik meningkatnya

7 Andrew Flowers, "Global Terrorism Declined Last Year-But not in the West", Five Thirty Eight, 30 Juni 2016.

8 Anthony H. Cordesman, "Broad Patterns in Global Terrorism 2014", Center for Strategic \& International Studies, 19 Juni 2015. 
skala kekerasan teror dalam beberapa tahun terakhir, ${ }^{9}$ walaupun fenomena tersebut bukan berarti justifikasi terhadap clash of civilization mengingat yang menjadi target dan korban dari serangan teroris mayoritas justru berasal dari kalangan Muslim sendiri. ${ }^{10}$

Benarkah Islam menjadi latar belakang doktrinal dari sepak terjang kekerasan yang dilakukan oleh para kelompok yang disebut teroris di atas? Sebuah survey kuesioner yang dilakukan oleh John L. Esposito dan Dalia Mogahed pada 2006 terhadap opini yang mewakili Muslim seluruh dunia menemukan sebuah fakta bahwa sangatlah mustahil jika mengatakan kelompok-kelompok tersebut bersuara atas nama Islam. Visi dan misi mereka hanya diadopsi oleh tidak lebih dari $1 \%$ populasi Muslim dunia yang total keseluruhannya mencapai angka sekitar 1.5 milliar dan mayoritas mereka mengatakan antikekerasan karena agama yang mereka anut menjunjung tinggi perdamaian. ${ }^{11}$ Namun, pendapat tersebut dicounter oleh pihak-pihak seperti situs ReligionofPeace.com yang mengatakan bahwa justru yang $1 \%$ dari Muslim itulah yang paling banyak bersuara di ruang publik global dan menunjukan Islam dalam realitas aktual. Angka $1 \%$ dari 1.5 milliar adalah jumlah yang tidak bisa disepelekan mengingat daftar sepak terjang mereka yang begitu mempengaruhi wacana publik dunia. ${ }^{12}$

\section{Ontologi Fenomena Islamisme}

Kiprah kekerasan dari kelompok-kelompok yang mengklaim dirinya sebagai pembawa panji kebesaran ajaran agama Islam mendapatkan perhatian yang cukup besar dari masyarakat dunia. Media-media mainstream internasional seolah tergelitik untuk terus meliput secara khusus setiap kali kelompok-kelompok tersebut melancarkan aksinya. Bukan hanya jenis aksi mereka yang selalu diilustrasikan sebagai tindakan horor dengan jatuhnya korban yang masif, tetapi juga dilengkapi dengan kekhawatiran akan adanya tindakan teror susulan yang mungkin terjadi kapan dan di mana

\footnotetext{
${ }^{9}$ George Arnett, "Religious Extremism Main Cause of Terrorism According to Report", The Guardian, 18 November 2014.

10 Anthony H. Cordesman, "Broad Patterns in Global Terrorism 2014".

${ }^{11}$ John L. Esposito dan Dalia Mogahed, Who Speaks for Islam?: What a Billion of Muslims Really Think (New York: Gallup Press, 2007).

12 Untuk lebih jauh mengenal pendapat ini serta pandangan yang relatif serupa, kunjungi www.religionofpeace.com. Laman tersebut juga berisi tautan-tautan ke laman-laman independen lain yang mempunyai persepsi serupa.
} 
saja. Wajar saja jika kemudian kelompok-kelompok dari elemen masyarakat Muslim ini dipandang sebagai ancaman terbesar bagi stabilitas perdamaian di tatanan global, dan hampir semua pihak yang bertanggung jawab dalam hal keamanan selalu mewaspadai potensi gangguan yang mungkin timbul dari pengaruh kelompokkelompok tersebut.

Potensi ancaman dari kelompok teroris religius memang bukan eksklusif berasal dari elemen masyarakat Muslim semata. Radikalisme agama nyatanya memang tercatat pernah menginspirasi kelompok-kelompok penganut agama lainnya. Namun, tak dapat dipungkiri bahwa ancaman dari kelompok radikal dari elemen masyarakat Muslim lebih menakutkan karena potensi transnasionalismenya. Jika kelompok ekstremis dari agama lain umumnya membatasi lingkup tujuan aksinya hanya sebatas kepentingan loal atau domestik, kelompok dari elemen masyarakat Muslim umumnya mempropagandakan cakupan tujuan aksi yang lebih luas. Pan-Islamisme baik dalam konteks geografis maupun ideologis biasanya dipropagandakan menjadi visi dan misi kelompok-kelompok ini dalam melancarkan aksinya.

Meski jumlah dari kelompok teroris Muslim ini terhitung sangat minoritas, kekhawatiran terhadap ancaman aksi mereka begitu besar. Kewaspadaan umumnya dilandasi dari asumsi bahwa ideologi mereka bisa saja menginspirasi masyarakat Muslim lainnya. Dengan populasi yang merepresentasikan hampir seperlima penduduk bumi dan penyebaran domisili geografis yang mencakup hampir seluruh penjuru dunia, perhatian terhadap potensi anomali dari gerakan agresivisme elemen masyarakat Muslim selalu menjadi sorotan pemangku kebijakan.

Terma umum yang merujuk kepada kemunculan gerakan agresif dari kalangan Muslim telah banyak bermunculan. Berbagai istilah yang digunakan untuk menggambarkan fenomena tersebut masing-masing menunjukkan kompleksitasnya. Latar belakang dari munculnya istilah-istilah tersebut adalah kecenderungan tren studi sosial-politik Islam sepanjang abad 20 yang dipicu oleh lahirnya gerakan al-Ikhwān al-Muslimūn di Mesir dan Revolusi Islam Iran. Dua fenomena itu dipandang sebagai kunci inspirasi bagi dinamika 
kehidupan kemasyarakatan dan pandangan politik komunitas Muslim dunia. ${ }^{13}$

Istilah awal yang paling banyak dipakai adalah "fundamentalisme Islam" dan "radikalisme Islam". Term lain kemudian banyak beredar seperti gerakan Islam (Islamic movements), Islam politik (political Islam), aktivisme Islam (Islamic activism), kebangkitan kembali Islam (Islamic revivalism/resurgence), dan aliran baru politik agama (new religious politics). Terakhir, muncul sebuah istilah baru yang meluas: Islamisme (Islamism).

"Fundamentalisme" merujuk kepada pandangan esensialis dalam memahami teks kitab suci sekaligus mengisyaratkan pola tradisionalisme dari gerakan tersebut. Menurut Hassan Hanafi, "fundamentalis" adalah istilah awal yang umum untuk menunjuk gerakan kebangkitan Islam, revivalisme Islam, dan gerakan atau kelompok Islam kontemporer, yang sering digunakan oleh peneliti Barat dan oleh banyak pemikir. ${ }^{14}$ M. 'Ābid al-Jābirī menguatkan pandangan tersebut bahwa istilah "Muslim fundamentalis" pada awalnya dicetuskan sebagai penanda bagi gerakan Salafiyah Jamāl al-Dīn al-Afghānī karena bahasa Eropa tidak punya istilah padanan yang tepat untuk menerjemahkan istilah "Salafiyah". ${ }^{15}$ Fundamentalisme menurut Ernest Gellner, adalah sebuah keyakinan akan kepemilikan eksklusif sebuah kebenaran yang unik. ${ }^{16}$ Mahmud Amīn al-'Alìm menerjemahkan-nya sebagai aliran pemikiran keagamaan yang cenderung menafsirkan teks-teks keagamaan secara rigid (kaku) dan literalis (tekstual), serta bersandar penuh pada tafsiran generasi awal pendahulu. ${ }^{17}$

Istilah berikutnya yang muncul adalah "puritanisme" seperti yang disodorkan oleh Khaled Abou El Fadl. Menurutnya, istilah fundamentalisme sangatlah problematis. Mengingat karakteristik-

\footnotetext{
13 Asef Bayat, "Islamism and Social Movement Theory", Third World Quarterly, Vol. 26, No. 6 (2005), 893.

${ }^{14}$ Hassan Hanafi, Aku Bagian dari Fundamentalisme Islam (Yogyakarta: Islamika, 2003), 110.

${ }^{15}$ M.'Ābid al-Jābirī, "Ḍarūrat al-Baḥth 'an Niqat al-Iltiqā' li Muwājahat al-Maṣīr al-Mushtarak", dalam Hassan Hanafi dan M. 'Ābid al-Jābirī, Hiwār al-Mashriq wa al-Maghrib (Beirut: Muassasat al-'Arabìyah, 1990), 32-34.

16 Ernest Gellner, Post-Modernism, Reason, and Religion (London dan New York: Routledge, 1992).

17 Abdurrahman Kasdi, "Fundamentalisme Islam Timur Tengah: Akar Teologi, Kritik Wacana, dan Politisasi Agama”, Tashwirul Afkar, No. 13 (2004), 20.
} 
nya, puritanisme lebih tepat untuk mengilustrasikan gerakan kelompok Islam yang dianggap memiliki pandangan absolutisme dan tanpa kompromi. ${ }^{18}$ Martin Riesebrodt melangkah lebih maju dengan menyebut fenomena gerakan ini sebagai "tradisionalisme radikal". ${ }^{19}$ Kepel dan Silvan bahkan langsung mengistilahkan gerakan ini dengan "Islam radikal". ${ }^{20}$

Dari titik inilah kemudian istilah "radikalisme" berkembang dan menyisir sisi-sisi gelap dari fenomena gerakan kelompok Muslim yang mengambil jalan kekerasan. "Radikalisme" dalam agama sering disebut dengan al-tatarruf al-dini yang mengandung arti berdiri di ujung, atau jauh dari pertengahan, atau dapat juga diartikan berlebihan dalam berbuat sesuatu. ${ }^{21}$ Akbar S. Ahmed mengatakan bahwa fundamentalisme Islam identik dengan radikalisme dengan menambahkan satu ciri dominan, yaitu vulgaritas, cenderung memakai kata-kata kasar serta kotor untuk menyudutkan lawan-lawan politiknya, bahkan mereka kadang tidak menyadari bahwa mereka mengklaim dan memperjuangkan kebenaran dengan cara-cara kasar, memuakkan dan menjijikkan. ${ }^{22}$ Radikalisme sebagai istilah bagi kelompok Islam yang agresif ini, menurut Juergensmeyer, dapat dipahami karena karakteristik sikap atau posisi yang mendambakan perubahan terhadap status quo dengan jalan penghancuran secara total, dan menggantikannya dengan yang sama sekali baru dan berbeda. Biasanya cara yang digunakan bersifat revolusioner yakni menjungkirbalikkan nilainilai yang ada secara drastis lewat kekerasan (violence) dan aksi-aksi yang ekstrem. ${ }^{23}$

Namun, peyorativitas istilah di atas menimbulkan impresi stereotyping ketika menggambarkan gerakan sosial Muslim secara

\footnotetext{
${ }^{18}$ Khaled Abou El Fadl, The Great Theft: Wrestling Islam from the Extremist (San Fransisco: Harper, 2005), 16-19.

19 M. Riesebrodt, Pious Passion (Berkeley, CA: University of California Press, 1993).

${ }^{20}$ Emmanuel Silvan, Radical Islam: Medieval Theology and Modern Politic (New Haven: Yale University, Press, 1990).

21 Ali Mustafa Yaqub, "Radikalisme dan Metode Memahami Teks Agama", makalah dalam Seminar Nasional Islam dan Terorisme, 2006.

22 Akbar S. Ahmed, Post-Modernism and Islam: Predicament and Promise (New York: Routledge, 1992), 171.

23 Marx Juergensmeyer, Teror atas Nama Tuban: Kebangkitan Global Kekerasan Agama (Jakarta: Nizam Press \& Anima Publishing, 2002), 5.
} 
general. Sebab, mayoritas gerakan itu justru sangat menghindari parktek-praktek kekerasan dan lebih memilih aktivitas cultural dan persuasif. Atas dasar itu, Keddie mengusulkan istilah "aliran baru politik religius" sebagai alternatif dari fundamentalisme atau radikalisme, karena istilah itu lebih netral serta menjelaskan baik isi politik gerakan, maupun sifat kontemporernya. ${ }^{24}$ Istilah lain yang muncul adalah "revivalisme" (kebangkitan) yang menekankan aspek keagamaan ketimbang visi politik gerakan-gerakan ini. Kebalikan dari istilah itu adalah "Islam politik" yang menekankan pada sifat politik mereka. Istilah terakhir ini banyak ditinggalkan mengingat karakter control dari ajaran Islam. Istilah Islam politik menurut banyak pengamat sama sekali tidak relevan, karena Islam sudah berpolitik sejak awal. ${ }^{25}$ Istilah mutakhir yang banyak dipakai adalah "aktivisme Islam" (Islamic activism) yang menekankan pada kiprah besar gerakan kelompok ini di bidang politik, sosial, dan kultural. Tetapi, sekali lagi, istilah tersebut terlalu umum, sehingga pilihan pun jatuh pada istilah "Islamisme". Islamisme merujuk kepada gerakan-gerakan aktivisme Islam di bidang sosial, kultural, dan politik yang luar biasa. Keluarbiasaan aktivisme yang dimaksud adalah gerakan itu tidak hanya menyasar perubahan pada aktivitas keagamaan normal, tetapi juga mengarah kepada revolusi perubahan sosial secara signifikan. ${ }^{26}$

\section{Genealogi Gerakan Islamisme}

Pelacakan historis gerakan Islamisme awal dalam Islam bisa dirujukkan kepada gerakan Khawārij, sedangkan representasi gerakan fundamentalisme kontemporer bisa dialamatkan kepada gerakan yang berafiliasi pada atau diilhami oleh Wahhābī Arab Saudi dan Revolusi Islam Iran. ${ }^{27}$

Secara makro, faktor yang melatarbelakangi lahirnya gerakan fundamentalis adalah situasi politik, baik di tingkat domestik maupun di tingkat internasional. Ini dapat dibuktikan dengan munculnya gerakan fundamentalis pada masa akhir khalifah 'Alī b.

\footnotetext{
${ }^{24}$ Keddie, "New Religious Politics: Where, When, and Why 'Fundamentalisms' Appear?", Comparative Studies in Society and History, Vol. 40, No. 4 (1998).

${ }_{25}$ Charles Hirschkind, "What is Political Islam?", Middle East Report, No. 205 (1997), 12-14.

${ }^{26}$ Bayat, "Islamism and Social Movement Theory", 894-895.

27 Azyumardi Azra, Pergolakan Politik Islam dari Fundamentalisme, Modernisme, bingga Post-Modernisme (Jakarta: Paramadina, 1996), 107.
} 
Abī Țālib, di mana situasi dan kondisi sosial-politik tidak kondusif. Pada masa khalifah 'Alī, perang saudara sedang berkecamuk hebat antara kelompok 'Alī dan Mu'āwiyah. Kedua belah pihak bersengketa pendapat tentang masalah pembunuh 'Uthmān dan masalah khilafah. Kelompok 'Alī bersikeras mengangkat khalifah terlebih dahulu lalu menyelesaikan masalah pembunuhan. Kelompok Mu'āwiyah menuntut penyelesaian masalah pembunuhan terlebih dahulu sebelum khalifah dipilih. Karena masing-masing kelompok sudah seperti air dengan minyak, maka rekonsiliasiperdamaian tak berarti lagi. Sesama Muslim itu saling bunuh, lalu damai dengan sistem tabkim (arbitrase). Dalam keadaan runyam semacam ini, Khawārij yang awalnya masuk dalam golongan 'Alī membelot dan muncul secara independen ke permukaan sejarah klasik Islam. Dengan latar belakang kekecewaan mendalam atas roman ganas dua kelompok yang berseteru dan slogan "lā hukm illā li Allāh", mereka berpendapat bahwa 'Alī dan Mu'āwiyah adalah kafir dan halal darahnya. 'Alī mereka bunuh, sedangkan Mu'āwiyah masih tetap hidup karena berpengawalan ketat. ${ }^{28}$

Kerunyaman situasi sosial, kultural, dan bahkan politik yang melibatkan ideologi juga begitu menghiasi sejarah abad pertengahan Islam. Di sepanjang periode itu muncul tokoh-tokoh seperti Ahmad b. Hanbal (780-855) dan Ibn Taymìyah (1263-1328) yang sama-sama menyuarakan revivalisme puritan. Mereka memandang bahwa pola kehidupan Muslim pada generasinya telah melenceng dari garis 'kemauan Tuhan' yang telah ditetapkan secara pasti karena maraknya 'tradisi luar' yang mendominasi aksi dan wacana baik di ranah sosial, kultural, maupun politik. Keduanya kemudian memelopori ajaran kembali pada al-Qur'ān dan Hadīth dengan meninggalkan ajaran yang berbau bid'ah dan khurafāt. ${ }^{29}$

Lima abad kemudian pola ini kembali dihidupkan oleh gerakan Wahhābī yang dipelopori oleh Muḥammad b. 'Abd al-Wahhāb (1703-1787). Tujuan dari gerakan Wahhābī ini juga ingin memurnikan ajaran Islam serta mengajak kembali kepada ajaran alQur'ān dan Sunnah Nabi, sebagaimana yang diamalkan oleh generasi awal umat Islam. Dalam perkembangan selanjutnya,

${ }_{28}$ G. Levi de la Vida, "Kharidjites", dalam Bernard Lewis et al. (eds.), The Encyclopaedia of Islam: New Edition, Vol. 4 (Leiden: E.J. Brill, 1990), 1074-1077.

29 Abdul Chalik, "Fundamentalisme dan Masa Depan Ideologi Politik Islam", ISLAMICA: Jurnal Studi Keislaman, Vol. 9, No. 1 (2014), 67. 
gerakan Salafiyah tidak hanya menyentuh dimensi purifikasi kredo dan ritual, tetapi juga mulai menyentuh dimensi intelektual dan politik. $^{30}$

Pada periode yang hampir bersamaan, pola pergerakan yang sama juga berkembang di Mesir yang distimulasi oleh pendudukan Napoleon Bonaparte yang membawa angin modernisasi. Tak lama setelah pendudukan Napoleon, Muhammad Ali Pasya (1769-1849) menindaklanjuti modernisasi tersebut dengan berbagai cara, di antaranya mengirimkan beberapa sarjana ke Eropa untuk belajar strategi perang, memperkenalkan model irigasi modern, membuka percetakan dan modernisasi pemerintahan. Ali Pasya memperkenalkan apa yang disebut dengan "westernisasi". Cara yang digunakan oleh Ali Pasya mendapatkan sambutan hangat di kalangan masyarakat Mesir, tetapi tidak sedikit pula yang mencurigai akan timbulnya dampak negatif dari modernisasi tersebut. Di antara yang bersikap hati-hati dan terkadang reaktif adalah Jamāl al-Dīn al-Afghānī (1839-1897) dan Muḥammad 'Abduh (1845-1905). Di berbagai kesempatan, khususnya ketika mengajar dan dalam tulisan-tulisannya di buletin al- Urwat al-Wuthqà (tali yang kokoh), al-Afghānī menekankan bahaya yang akan ditimbulkan oleh Barat dan pengaruhnya di dunia Islam, dengan menekankan perlunya persatuan di kalangan umat Islam dalam rangka menangkal bahaya ini. ${ }^{31}$

Baik al-Afghānī maupun 'Abduh menyerukan kepada umat Islam agar kembali kepada ajaran agama yang benar dengan mendengungkan purifikasi dan meninggalkan bid'ah. Keduanya tidak menolak modernisasi, tapi bagaimana menyikapi dengan bijak isu-isu modern dalam kerangka keislaman. Sementara murid 'Abduh, Muhammad Rashīd Riḍā (1865-1935) yang menjadi penggerak kebangkitan Islam sesudahnya mementingkan perlunya penegakan kembali institusi khilāfah sebagai alternatif terhadap nasionalisme yang ia tantang. Premis yang digunakan adalah pemerintahan Islam adalah pemerintahan yang berasal dari wahyu, dan tidak ada kehidupan normal dan bahagia kecuali dengan pemerintahan semacam itu. Pemikiran Rị̣ā sebagai bentuk kritik

\footnotetext{
${ }^{30}$ Edi Susanto, "Kemungkinan Munculnya Paham Islam Radikal di Pesantren”, Tadris, Vol. 2, No. 1 (2007), 3.

${ }^{31}$ David Sagiv, Islam: Otentisitas Liberalisme, terj. Yudian W. Asmin (Yogyakarta: LKiS, 1997), 10-25.
} 
terhap model pemerintahan yang dikembangkan oleh pemerintah Mesir waktu itu.

Gema kebangkitan dan fundamentalisme mencapai puncaknya pada abad 20 ketika kekhalifahan Islam Turki 'Uthmānī bubar. Pada 1928 gerakan al-Ikhwān al-Muslimūn (IM) muncul yang dipelopori oleh Hasan al-Bannā. Al-Bannā adalah aktivis pada kelompok kajian al-Manār yang dipimpin oleh Rị̣ā dan secara konsisten mengikuti ajaran-ajaran konservatif Riḍa. Pada awalnya, IM berkonsentrasi pada gerakan Salafì dan sama sekali tidak masuk ke area politik, tapi belakangan ketika pengikutnya semakin banyak dan mendapat tempat di hati masyarakat Mesir, IM kemudian menjadi kelompok radikal yang dalam gerakannya selalu bersentuhan dengan wilayah kekerasan. ${ }^{32}$

Demikian pula ketika ide-ide Sayyid Qutb (1906-1966) mulai masuk ke model gerakan IM. Meskipun awalnya bukan anggota, tapi setelah kematian al-Bannā justru Quṭb yang menjadi ikon gerakannya. Di samping para pendahulunya yang memengaruhi alam pikir Quṭb, ia juga dipengaruhi oleh al-Mawdūdī. ${ }^{33}$ Salah satu doktrin Qutb adalah konsep "jahiliyah modern”, yakni modernitas sebagai "barbaritas baru". Meskipun istilah jahiliyah modern diadopsi dari al-Mawdūdī, tetapi konsep yang dikembangkan oleh Quṭb lebih berpengaruh. Menurut Qutb, jahiliyah modern adalah situasi di mana nilai-nilai fundamental yang diturunkan Tuhan kepada manusia diganti dengan nilai-nilai palsu (artificial) yang berdasar hawa nafsu duniawi. Jahiliyah modern merajalela di muka bumi ketika Islam kehilangan kepemimpinan atas dunia, sementara pada pihak lain Eropa mencapai kejayaannya.

Untuk menumpas jahiliyah modern, menurutnya masyarakat Muslim harus melakukan taghyir al'aqlìyah, yakni perubahan fundamental dan radikal, bermula dari dasar kepercayaan, moral dan etikanya. Dominasi atas manusia semata-mata dikembalikan kepada Allah, di mana Islam sebagai sistem holistik. Jihad harus dihadapkan dengan modernitas. Tujuan akhir jihad adalah membangun kembali "kekuasaan Tuhan" di muka bumi, di mana sharíah memegang supremasi: shari'ah bukan dalam pengertian

\footnotetext{
32 Leonard Binder, Islamic Liberalism (Chicago: Chicago University Press, 1988), 271.

${ }^{33}$ Ibid., 270.
} 
sempit sebagai sistem hukum, tetapi dalam pengertian lebih luas yakni cara hidup menyeluruh sebagaimana digariskan Allah. Quṭ memahami bahwa cara yang tepat untuk mengembalikan kekuasaan Allah di muka bumi dengan cara melakukan jihad secara total, fisik maupun non-fisik. ${ }^{34}$

Pemikiran Qutb inilah yang kemudian banyak menginspirasi perkembangan gerakan Islamisme berhaluan keras berikutnya. Retorika wacana yang dibangun Quṭ diperkuat oleh dramatisasi proses eksekusi hukum gantungnya di ranah publik cukup mengobarkan semangat partisipan Islamisme untuk mewujudkannya di realitas. Salah satu tokoh yang paling terinspirasi oleh sosok Quṭb adalah 'Abd Allāh 'Azzām yang kemudian menjadi mentor dari Bin Laden, sekaligus menjadi partnernya dalam menggagas organisasi Al Qaeda. Genealogi dari kelompok-kelompok Islamisme dewasa ini bisa dilihat dari tabel di bawah ini.

Tabel 3:

Genealogi Kelompok-kelompok Islamisme

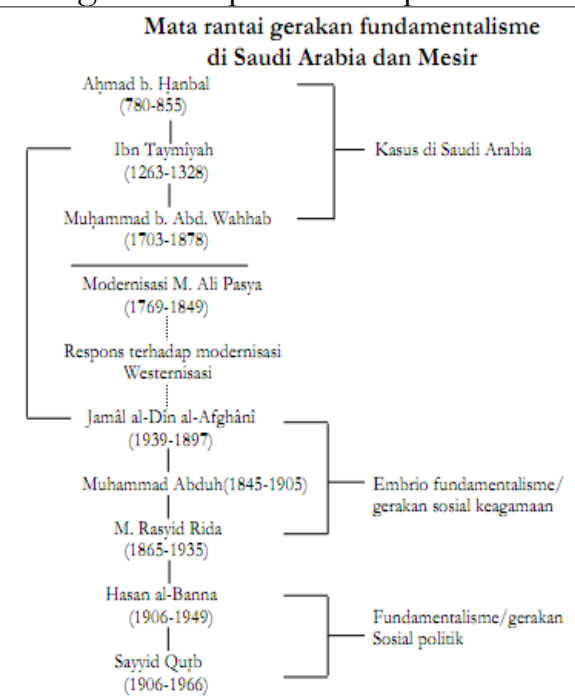

Sumber: Abdul Chalik, Islam dan Kekuasaan. ${ }^{35}$

Ilustrasi lain dari genealogi timbulnya gerakan kelompok Islam agresif pasca-Ḥasan al-Bannā yang beberapa di antaranya diidenti-

\footnotetext{
${ }^{34}$ Azra, Pergolakan Politik Islam, 120-121.

35 Abdul Chalik, Islam dan Kekuasaan (Yogyakarta: Interpena, 2012), 45.
} 
fikasi sebagai aktivis dalam aksi-aksi yang mengarah ke terorisme adalah sebagai berikut: ${ }^{36}$

\section{Bagan 1:}

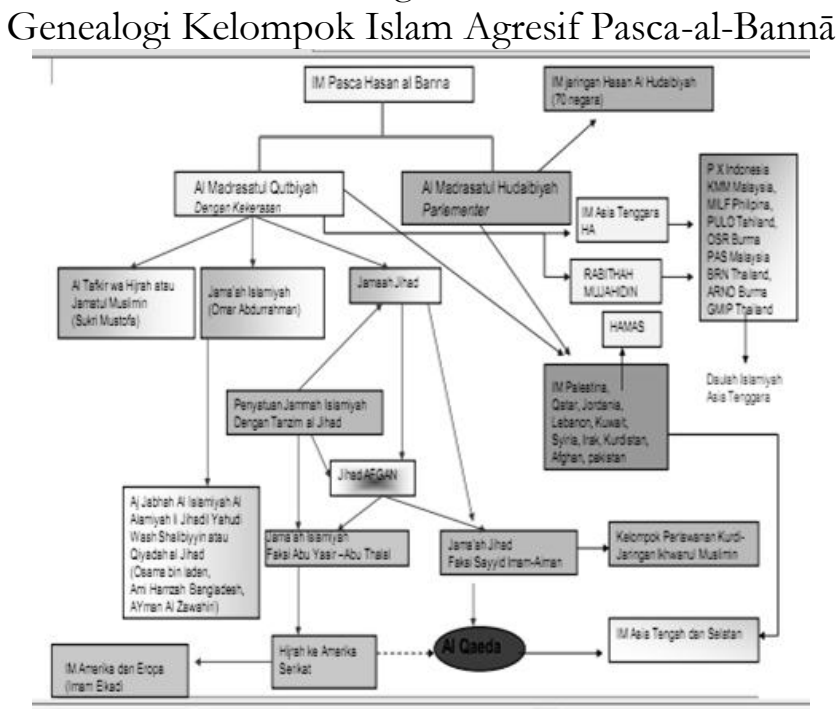

Sumber: Data Lakpesdam NU Pusat, Jakarta.

\section{Doktrinal Vs. Politis: Polemik Diskursus Motif Islamisme Radikal}

Pemetaan hubungan antara inspirasi ideologis doktrin keagamaan dengan praktek kekerasan berupa terorisme telah lama menjadi bahan perdebatan yang panjang. Ibarat lingkaran logika lebih dulu mana antara ayam dan telur, perbedaan pendapat di kalangan akademisi seputar konsep religious terrorism berangkat dari titik awal perspektif yang mereka bangun. Sebagian berpendapat bahwa agama hadir lebih awal dan memberi inspirasi hingga justifikasi 'langit' bagi dihalalkannya atau bahkan dimuliakannya aksi-aksi kekerasan. Sebagian lain berpandangan bahwa ideologi agama datang belakangan sebagai rasionalisasi, apologi atau bahkan cover bagi tujuan-tujuan politis dari aksi kekerasan teror yang dilancarkan. ${ }^{37}$ Namun, secara garis besar, setidaknya terdapat tiga aliran mainstream yang mempunyai perbedaan pandangan

\footnotetext{
36 Data Lakpesdam NU Pusat Jakarta.

37 David Gibson, "Does religion Cause Terrorism? It's Complicated", The Huffington Post, 31 Agustus 2011. Diakses dari laman http://www.huffingtonpost.com/2011/08/31/religion-terrorism_n_944143. html tanggal 17 April 2017.
} 
signifikan. Pertama, mereka yang percaya bahwa pembenaran terhadap aksi-aksi kekerasan hingga terorisme adalah produk inheren dari doktrin keagamaan. Kedua, mereka yang memandang bahwa terorisme adalah perkara yang profan, sama sekali tak ada hubungannya dengan agama. Ketiga, pendapat yang menyebutkan bahwa terorisme adalah sinkretisme serta modifikasi interrelatif antara politik dan agama.

David C. Rapoport adalah tokoh yang dianggap pionir dalam mendeteksi eksistensi pengaruh signifikan agama dalam aksi-aksi teror yang mengguncang dunia. Religious terrorism, menurutnya, adalah sebuah bentuk kekerasan baru yang berbeda dengan aksi terorisme konvensional karena peran inspirasional dari teks-teks kitab suci serta contoh-contoh sejarah yang disakralkan. ${ }^{38}$ Bruce Hoffman menguatkan pendapat ini dengan menekankan bahwadalam 'terorisme agama'-dalil-dalil suci secara unik memberikan pembenaran dan legalitas terhadap aksi teror kekerasan. ${ }^{39}$ James W. Jones lebih jauh menjelaskan bahwa nilai-nilai sakral yang menjadi karakteristik 'terorisme agama' justru menjadi titik sentral yang menyebabkan fenomena terorisme ini mempunyai skala mematikan yang lebih masif dan cakupan yang lebih luas sehingga sangat sulit untuk mencari pola remedy-nya dibandingkan tengan terorisme konvensional. ${ }^{40}$ Tiga pendapat di atas membantah pakem pandangan yang menyatakan bahwa terorisme agama adalah bentuk lain dari terorisme konvensional yang bercirikan militansi sayap kanan. ${ }^{41}$ Namun, tiga pendapat di atas kurang mengurai secara spesifik konstruksi doktrin-doktrin sakral yang dipakai para pelaku teror serta jarang menyebut faktor lain yang menyebabkan mengapa nilai-nilai sakral agama menjadi inspirasi teror bagi sebuah kelompok tetapi tidak berefek pada kelompok lainnya.

Senada dengan pendapat di atas, akademisi lain mencoba lebih spesifik merasionalisasikan peran besar inspirasi agama dalam aksi terorisme. Meneliti para tahanan terorisme, Amos N. Guiora

38 David C. Rapoport, "Fear and Trembling: Terrorism in Three Religious Traditions", American Political Science Review, Vol. 78, No. 3 (1984).

${ }^{39}$ Bruce Hoffman, "Holy Terror: The Implications of Terrorism Motivated by a Religious Imperative," Studies in Conflict and Terrorism, Vol. 18, No. 4 (1995).

40 James W. Jones, Blood That Cries Out From the Earth: The Psychology of Religious Terrorism (New York: Oxford University Press, 2008).

41 Walter Laqueur, The Age of Terrorism (Boston: Little, Brown and Company, 1987). 
berkesimpulan bahwa eksistensi terorisme agama benar-benar nyata dan benar-benar religious karena para pelaku menyatakan bahwa aksi kekerasan itu adalah tugas 'langit'. ${ }^{42}$ Paul Cliteur memperkuat pandangan Amos seputar irasionalitas justifikasi kekerasan dalam agama di atas dengan merujuk kepada kisah sakral yang dipercayai baik oleh ajaran Yahudi, Kristen, maupun Islam mengenai kesediaan Abraham untuk memenggal kepala anaknya demi memenuhi perintah Tuhan. ${ }^{43}$ Inspirasi doktrinal dalam terorisme, menurut Jonathan Fine, begitu kentara dalam aksi-aksi kekerasan yang dieksekusi oleh elemen-elemen kelompok Muslim. Konsep-konsep seperti "jihad" dan "syahid" begitu mendominasi latar belakang pemikiran kelompok Muslim ekstrem. ${ }^{44}$ Pendapat yang sama juga diadopsi oleh David Bukay. Setelah mengkaji beberapa peristiwa bom bunuh diri di wilayah Timur Tengah, ia berargumen bahwa aksi-aksi tersebut sangat terkait erat secara doktrinal dengan ajaran Islam." All Muslim suicide bombers justify their actions with their religion and, more specifically, with the concept of jihad". ${ }^{45}$ Sementara Ayan Hirsi Ali berpendapat bahwa terorisme agama khususnya terorisme Islam adalah sesuatu yang nyata dan buktinya begitu gamblang secara historis. Hirsi Ali banyak mengambil contoh dari praktik-praktik 'kekerasan' berupa ekspedisi perang penaklukan yang dilakukan oleh Muhammad selama periode Madinah. ${ }^{46}$ Pendapat-pendapat di atas sayangnya hanya menyoroti "apa yang dikatakan" (what they say) oleh para pelaku teror. Analisisnya kurang mampu menjawab dimensi politik serta faktor kontekstual-eksternal lain dari tujuan di balik aksi-aksi terorisme yang dicap bernuansakan agama. Sehingga, pertanyaan "apakah agama dalam konteks religious terrorism itu cukup hanya dengan

\footnotetext{
42 Amos N. Guiora, Freedom From Religion: Rights and National Security (Oxford: Oxford University Press, 2009)

${ }^{43}$ Paul Cliteur, "Why Religious Terrorism is Really Religious", Church and State, 2015. Diakses dari laman http://churchandstate.org.uk/2017/01/why-religiousterrorism-is-really-religious/ tanggal 13 April 2017.

${ }^{44}$ Jonathan Fine, "Contrasting Religious and Secular Terrorism", The Middle East Quarterly, Vol. 15, No. 1 (2008), 27-36.

45 David Bukay, "The Religious Foundatios of Suicide Bombings", The Middle East Quarterly, Vol. 13, No. 4 (2006), 27-36.

46 Ayan Hirsi Ali, "Islam is Religion of Violence", Foreign Affairs, 9 November 2015.
} 
menjadi inspirator saja atau juga harus mengkristal dalam agenda capaian tujuan?" masih belum terjawab.

Beberapa tokoh mencoba menyoroti bahwa terorisme agama bisa dikarakterisasikan berdasarkan aspek kontekstual-historis dari agama itu sendiri serta aspek sakralitas dari tujuan yang hendak dicapainya. Bernard Lewis misalnya menyatakan bahwa Islam dan Kristen lebih mungkin mengembangkan terorisme agama karena romantisme kejayaannya dalam sejarah. Ketika mereka berada di posisi sub-ordinal, potensi kekerasan dengan justifikasi agama akan semakin besar untuk muncul. ${ }^{47}$ Samuel P. Huntington meneruskan thesis Lewis dengan menambahkan bahwa inspirasi kekerasan dalam agama, khususnya Kristen dan Islam, begitu kuat. Selain karena banyak seruan-seruan kekerasan eksplisit yang tersebar dalam kitab sucinya, Islam dan Kristen sama-sama mengklaim diri sebagai doktrin Messianic superior akhir zaman dan berkarakter ekspansionis, dalam artian menuduh pihak eksternal sebagai sesat dan harus ditarik ke dalam komunitas dalam rangka penyelamatan. ${ }^{48}$ Huntington, selanjutnya, menambahkan bahwa Islamlah yang paling mungkin menjadi inspirasi tindakan teror di abad milenium ini karena banyak diinterpretasikan dengan pendekatan mengembalikan romantisme kejayaan di tengah kondisi keterpurukan. Fakta mutakhir juga menunjukkan bagaimana kekerasan begitu menyebar luas di dunia Muslim. ${ }^{49}$ Mark Sedgwick dan Heather S. Gregg menawarkan konsep "goal analysis" dalam mengidentifikasi karakteristik terorisme agama. Menurut Sedgwick, terorisme agama pasti menempatkan argumentasi teks-teks suci sebagai tujuan akhir dari aksi kekerasan. Tujuan sementara (immediate goal)-nya mungkin saja sangat politis, misalnya untuk menggulingkan pemerintahan atau mencapai kemerdekaan. Tetapi, penghujung tujuan terorisme agama diyakini oleh pelakunya bermuara pada pemenuhan tugas dan kewajiban yang telah ditetapkan dari 'langit'. ${ }^{50}$ Sedangkan Gregg berpandangan bahwa baik pada immediate maupun ultimate

\footnotetext{
${ }^{47}$ Bernard Lewis, "The Roots of Muslim Rage", Atlantic Monthly, Vol. 266, No. 3 (1990).

48 Samuel P. Huntington, “The Clash of Civilizations?", Foreign Affairs, Vol. 72, No. 3 (1993).

49 Samuel P. Huntington, “The Age Muslim Wars”, Newsweek (Special Edition), Desember 2001-Februari 2002.

${ }^{50}$ Mark Sedgwick, "Al Qaeda and the Nature of Religious Terrorism”, Terrorism and Political Violence, Vol. 15, No. 4 (2004).
} 
goals-nya, setiap peristiwa terorisme dapat dikategorikan sebagai religious terrorism jika mengandung satu dari tiga tujuan yang dipandang sakral, yaitu: apocalyptic (memusnahkan entitas generasi atau lingkungan dan menggantinya dengan yang baru), membentuk sebuah tata pemerintahan yang religius, atau mendirikan sebuah negara yang religius. ${ }^{51}$

Di ujung kontras yang lain, banyak pula akademisi yang meragukan eksistensi dari formulasi konsep terorisme agama. David Tucker menyatakan bahwa religious terrorism adalah sebuah konsep yang absurd karena batasan terminologisnya yang rancu dan memusingkan. ${ }^{52}$ Walter Laqueur berpedapat bahwa apa yang sering disebut dengan terorisme agama pada dasarnya adalah bentuk baru dari terorisme sayap kanan (right-wing terrorism) dan lebih terisnpirasi oleh ideologi nasionalisme ketimbang agama. ${ }^{53}$ Sejalan dengan Laqueur, Robert Pape berkesimpulan bahwa aksi teror bom bunuh diri di mana pun di dunia ini sama sekali tidak ada hubungannya dengan inspirasi agama, tetapi lebih digerakkan oleh tujuan yang bersifat taktis. Membandingkan pola bom bunuh diri yang dilakukan oleh kelompok 'Islamis' dengan kelompok Macan Tamil Eelam yang Hindu, Pape menyatakan bahwa benang merah dari aksi-aksi itu lebih berdasarkan pada alasan perlawanan mengakhiri pendudukan dan penjajahan. Fokus pada inspirasi agama di balik teror adalah sebuah usaha pengalihan dari isu yang sebenarnya. ${ }^{54}$ Mia Bloom juga berpandangan bahwa terorisme seperti bom bunuh diri lebih bersifat strategis, bertujuan politis serta jauh hubunganya dengan agama. Menurutnya, aksi terorisme hanyalah sebuah sarana untuk mencapai sebuah tujuan (a means to an end) dengan taktik yang menimbulkan efek menggemparkan. ${ }^{55}$ Kelemahan beberapa pendapat yang menegasikan dan mendowngrade-kan eksistensi terorisme agama di atas adalah ketika dihadapkan pada kasus terorisme seperti Aum Shinrikyo yang sama

51 Heather S. Gregg, "Defining and Distinguishing Secular and Religious Terrorism", Perspectives on Terrorism, Vo. 8, No. 2 (2014).

${ }^{52}$ David Tucker, "What is New about the New Terrorism and How Dangerous is It?", Terrorism and Political Violence, Vol. 13, No. 3 (2001).

${ }^{53}$ Laqueur, The Age of Terrorism.

${ }^{54}$ Robert Pape, Dying to Win: The Strategic Logic of Suicide Terrorism (New York: Random House, 2005).

${ }_{55}$ Mia Bloom, Dying to Kill: The Allure of Suicide Bombing (New York: Columbia University Press, 2005). 
sekali tak bertujuan politis dan semata apokaliptik. Verifikasi pendapat tersebut juga kurang memuaskan dalam menjawab kasuskasus terorisme yang dikaitkan dengan $\mathrm{Al}$ Qaeda.

Perspektif lebih komprehensif dari pandangan yang meragukan eksistensi religious terrorism ditawarkan oleh Mark Juergensmeyer. Menurutnya, "religion is not the problem". Isu agama hanya muncul ketika fenomena mencapai level brutal sementara alasan dan tujuannya tampak begitu irrasional. Meneliti berbagai kekerasan yang dilakukan oleh kelompok-kelompok berlatarbelakang Islam, Kristen, Hindu, Sikh dan Buddha, Juergensmeyer berkesimpulan bahwa agama dalam terorisme hanya merupakan strategi dan simbol semata, sementara aksi terorisme itu sendiri adalah atraksi kekerasan di ranah publik yang tujuannya lebih bersifat kosmik. ${ }^{56}$ Agama yang berperan hanya sebagai simbol dalam terorisme paling banyak disuarakan oleh para akademisi yang cenderung membela citra Muslim. Esposito, misalnya, menyatakan bahwa memberikan label simplisistik seperti terorisme Islam adalah sebuah simbolisasi yang mengerdilkan permasalahan. Setiap fenomena yang berkembang dalam entitas masyarakat keagamaan adalah hasil dari evolusi sosio-politis dan kultural. Kekerasan yang sering diasosiasikan dengan terorisme sebetulnya lebih dipengaruhi oleh tuntutan-tuntutan pragmatis serta mengarah pada penyesuaian dengan lingkungan global yang saling terkait. ${ }^{57}$ Pendapat serupa disampaikan oleh Manal Omar bahwa jika serangkaian aksi kekerasan terjadi di beberapa belahan dunia Muslim bukan berarti peristiwa tersebut adalah cerminan dari agama yang dianut. Peristiwa terorisme adalah produk dari situasi dan kondisi sosialpolitik yang kompleks yang di antaranya merupakan efek warisan kolonialisme serta kontestasi kepentingan negara-negara adidaya yang meninggalkan jejak permusuhan di mana-mana. Agama, di sisi lain, bisa saja punya andil dalam konflik tersebut, namun bukan karena faktor ajarannya, melainkan lebih karena bagaimana ajaran itu ditafsirkan secara manipulatif dan disalahgunakan. ${ }^{58}$ Pemilahan

56 Mark Juergensmeyer, Terror in the Mind of God: The Global Rise of Religious Violence (Berkeley: University of California Press, 2000).

57 John L. Esposito, Islamic Threat: Myth or Realitiy?, Edisi Ketiga (New York: Oxford University Press, 1999), 257-259.

58 Manal Omar, "Islam is the Religion of Peace", Foreign Affairs, 9 November 2015. 
religious terrorism dari terorisme sekuler sendiri begitu bermasalah baik secara konseptual maupun empiris, menurut Jeroen Gunning dan Richard Jackson. Premis-premis khusus yang menjadi dasar pengidentifikasian motif, perilaku serta tujuan terorisme religius cenderung rancu, tumpang tindih, dan sama sekali sukar dibedakan dengan terorisme sekuler sehingga memerlukan pendalaman kualifikasi lebih lanjut. Konsep terorisme religius adalah hasil dari sebuah perspektif politis terhadap agama dengan menempatkannya pada situasi historis tertentu kemudian menganalisanya dalam kerangka struktur kekuasaan. Maka tak heran jika apa yang disebut religius sukar sekali dibedakan dengan yang sekuler atau politis. Celakanya, formulasi terorisme religius ini seringkali dimanfaatkan untuk mendeligitimasi aktor-aktor politik tertentu serta melegalkan aksi-aksi counter-terorisme yang di luar batas toleransi. ${ }^{59}$ Dengan menganalisis wacana seputar terorisme Islam, Jackson bahkan melangkah lebih jauh dengan menuding istilah terorisme religius, dan lebih spesifiknya lagi terorisme Islam, sebagai sebuah narasi diskursus yang memang sengaja dibentuk meskipun entitas riilnya begitu sumir. ${ }^{60}$

Pendapat mainstream ketiga seputar konsep terorisme agama menandai adanya fusi atau keterkaitan yang tak terpisahkan antara agama dan politik yang menjadi motif, pemicu, serta tujuan dari tindakan kekerasan. Patricia Crone menyajikan konsep "Islamisme" sebagai penggerak utama dari kekerasan yang merupakan perkawinan antara doktrin Islam dan politik. Muslim, menurut Crone, percaya bahwa semua bentuk praktek apa pun di kehidupan ini harus berdasarkan aturan dari Tuhan. Dalam sejarahnya, umat Islam telah berhasil menciptakan sebuah wadah lingkungan dan sistem yang memfasilitasi kehidupan individual dan kolektif berdasarkan 'kehendak Tuhan'. Namun, masalah bagi Muslim timbul ketika wadah lingkungan serta sistem itu kemudian dikuasai dan dimonopoli oleh pihak non-Muslim. Dalam konteks seperti itulah, Islamisme terbentuk dengan tujuan untuk mengembalikan kejayaan Muslim dan dapat diterapkannya kembali ajaran Islam dalam kehidupan. Aksi-aksi kekerasan bahkan sampai

\footnotetext{
59 Jeroen Gunning dan Richard Jackson, 'What's so 'Religious' about 'Religious' Terrorism", Critical Studies on Terrorism, Vol. 4, No. 3 (2011).

${ }^{60}$ Richard Jackson, “Constructing Enemies: 'Islamic Terrorism' in Political and Academic Discourse", Government and Opposition, Vol. 42, No. 3 (2007).
} 
skala yang menghancurkan pun adalah sebuah perjuangan yang harus ditempuh demi menciptakan sebuah wadah di mana aturan Tuhan bisa diberlakukan. ${ }^{61}$ Paul Berman hampir satu ide dengan pemikiran Crone di atas dengan menegaskan bahwa aksi terorisme yang dilakukan oleh kelompok Islamis tersebut menyerupai semangat liberalisme dalam aksi-aksi teroris sekuler tapi dengan semangat dan nuansa doktrin religius yang sangat kental. ${ }^{62}$ Nuansa serupa dengan pendekatan yang sedikit berbeda dinyatakan oleh Jessica Stern. Bentuk kekerasan berlatar belakang agama seperti jihad dalam Islam telah menjelma menjadi tren dan begitu menyedot banyak perhatian publik. Tren ini kemudian dipilih sebagai jalan untuk mengekspresikan perlawanan terhadap dominasi politik status quo. ${ }^{63}$

\section{Fenomenologi Islamisme: dari Motif ke Aksi}

Meski berbeda dalam menyimpulkan peran agama dalam terorisme, tiga teori mainstream di atas mempunyai keidentikan dalam pendekatan analisis. Benang merahnya tergambar jelas dalam dua ranah besar yang menjadi dimensi fokus pembahasan; dimensi agama sebagai doktrin dan dimensi politis yang inheren menyertai setiap aksi tindakan terorisme. Menakar motif mana yang paling dominan dalam setiap aksi Islamisme dapat berangkat dari tinjauan fenomenologis.

Terdapat setidaknya dua perspektif umum yang dipakai oleh para pengamat dalam melakukan pendekatan studi terhadap fenomena gerakan Islamisme ini. Menurut perspektif pertama, gerakan Islamisme adalah sebuah bentuk antimodernitas yang muncul sebagai respon antidote terhadap pembaharuan yang dihasilkan oleh Barat. Berdasarkan perspektif ini, Islamisme muncul dengan langsung menempatkan dirinya sebagai musuh dari Barat yang menjadi pionir dari modernisasi. Perspektif antimodernitas ini juga terpolarisasi menjadi dua bagian; perspektif clash (konfrontasi langsung) seperti yang digagas oleh Bernard

\footnotetext{
${ }^{61}$ Patricia Crone, "Jihad: Idea and History", Open Democracy, 1 Mei 2007.

${ }^{62}$ Paul Berman, Terror and Liberalism (New York: W.W. Norton, 2004).

${ }^{63}$ Jessica Stern, Terror in the Name of God: Why Religious Militants Kill (New York: Harper Collins, 2009).
} 
Lewis dan dipopulerkan oleh Samuel Huntington, ${ }^{64}$ serta perspektif regressive monism (mencari formulasi anti-Barat dengan menghidupkan romantisme sejarah awal) versi Alberto Melucci dan Alain Touraine. ${ }^{65}$ Berdasarkan perspektif pertama ini gerakan Islamisme akan selalu membawa jargon perang melawan Barat, sehingga apapun yang datang dari Barat dipandang sebagai target untuk dimusuhi dan dicarikan formulasi kebalikannya.

Perspektif kedua menyimpulkan bahwa gerakan tersebut adalah fenomena manifestasi dan sekaligus juga respon terhadap perkembangan postmodernitas. Menurut perspektif ini, Islamisme muncul sebagai sesuatu yang menjadi pembeda, menyuarakan otonomi kultural, entitas politis alternatif, serta kritik moralitas idologis terhadap sekularisme modernitas. Michel Foucault menyebut Revolusi Iran sebagai contoh terbaik dari fenomena postmodernitas di mana revolusi itu muncul sebagai representasi dari munculnya 'spirit di tengah kondisi dunia yang tanpa spirit'. Anthony Giddens memandang munculnya Islamisme sebagai fenomena krisis yang melanda modernitas. ${ }^{67}$ Manuel Castells merujuk Islamisme sebagai "the exclusion of the excluders by the excluded". ${ }^{68}$ Sementara Esposito mendefinisikan Islamisme sebagai sebuah proses pencarian bentuk identitas, otentisitas dan komunitas, serta semangat untuk membangun konsep makna dan juga struktur keharmonisan dalam kehidupan pribadi dan masyarakat. ${ }^{69}$ Singkatnya, perspektif postmodernitas memandang bahwa Islamisme adalah gerakan untuk membentuk sebuah sistem kehidupan yang spesifik dan pasti di tengah dunia yang penuh dengan ketidakpastian.

\footnotetext{
${ }^{64}$ Huntington, The Clash of Civilizations; Bernard Lewis, "Roots of Muslim Rage", Atlantic Monthly, September 1990; dan Bernard Lewis, What Went Wrong (London: Phoenix, 2002).

65 Alberto Melucci, Challenging Codes: Collective Action in the Information Age (Cambridge: Cambridge University Press, 1996), 104; A Touraine, The Return of the Actor (Minneapolis: University of Minnesota Press, 1988), 64.

${ }^{66}$ Michel Foucault, "An Interview with Michel Foucault", Akhtar, No. 4 (1987), 43.

67 Anthony Giddens, Social Theory and Modern Society (California: Stanford University Press, 1987), 50.

${ }^{68}$ Manuel Castells, The Power of Identity (Oxford: Blackwell, 1997), 9.

${ }^{69}$ John L. Esposito, "Religion and Political Affairs: Political Challenges", SAIS Review: A Journal for International Affairs, Vol. 18, No. 2 (1998), 20.
} 
Dua perspektif fenomenologis di atas sangat membantu dalam menganalisis titik berangkat sebuah gerakan Islamis membangun aktivismenya. Sedikitnya dibutuhkan tiga langkah awal untuk sampai kepada kesimpulan tingkat kedominanan faktor yang menjadi titik berangkat tersebut. Langkah pertama dimulai dengan memilah struktur dari gerakan tersebut ke dalam elemen-elemen inti yang menjadi pilar. Standar dari pilar penggerak sebuah aktivisme paling tidak terdiri dari tokoh kunci, simbol yang digunakan, serta fokus wacana yang menjadi concern di internalnya. Langkah berikutnya adalah menentukan parameter dominasi faktor motif penggerak dengan menempatkan motif doktrinal di satu kutub dan motif politis di kutub berlawanannya. Langkah terakhir adalah menempatkan masing-masing elemen pilar ke dalam parameter tersebut dengan mengaplikasikan kedua perspektif fenomenologis di atas. Konsekuensi dari langkah-langkah itu akan menghasilkan sebuah kesimpulan yang menunjukkan faktor motif dominan yang menjadi mesin penggerak Islamisme.

Artikulasi motif-motif dari gerakan Islamisme akan tetap berbentuk potensi hingga akhirnya mereka mengejawantahkannya dalam bentuk aksi. Eksekusi motif tersebut pada dasarnya selalu bersifat kolektif meskipun setiap gerakan Islamisme selalu disorot berdasarkan simbolisme yang direpresentasikan oleh tokoh utama penggeraknya. Seorang tokoh simbolik yang menjadi patron selalu dikelilingi oleh klien yang merupakan individu-individu yang siap menerjemahkan motif dan simbol dari gerakan tersebut menjadi aksi.

Ada setidaknya tiga teori social movement yang menjelaskan kenapa individu-individu kemudian terlibat dalam sebuah kelompok lalu bergerak bersama; collective behavior, resources mobilization, dan imagined solidarity. Ketiga teori itu sama-sama menyebutkan bahwa aksi kolektif terjadi setelah terbentuknya identitas kolektif yang tersusun dari rasa kebersamaan (perasaan yang common) dan solidaritas. Bangunan struktur sosial terbentuk karena adanya persamaan persepsi dan rasa yang kemudian mendorong mereka untuk bertindak secara kolektif. Namun, ketiganya berbeda dalam menempatkan faktor apa yang paling mempengaruhi individu untuk bergabung dalam sebuah kelompok kemudian menentukan bentuk aksinya secara kolektif. Menurut teori collective behavior, aksis utama dari faktor yang menggerakkan 
individu dalam sebuah kelompok adalah adanya konsep, ideologi, pandangan, keyakinan (beliefs), dan nilai (values) yang dianut bersama dan mempersatukan. ${ }^{70}$ Dalam perspektif teori ini, aktoraktor yang terlibat dalam mobilisasi kelompok tidak membawa pengaruh yang signifikan. Bahkan, menurut teori crowd (pengembangan dari collective behavior), aksi kolektif bisa terjadi begitu saja (spontaneous) karena didorong oleh persamaan cara pandang. ${ }^{71}$ Sementara teori resources mobilization menempatkan penekanan pada faktor motif rasional para aktornya yang mempengaruhi dan mendorong mobilisasi kelompok. Eksistensi ideologi atau konsep metafisik memang menjadi ruh penggerak kelompok, tetapi bentuknya akan sangat dipengaruhi oleh ide-ide yang dicetuskan oleh para aktornya. ${ }^{72}$ Imagined solidarity melangkah lebih jauh ke fenomenologi motif kolektif. Menurut teori ini, aksi kelompok sebenarnya terdiri dari motif-motif yang terfragmentasi dan sama sekali tidak homogen. Kesamaan pandangan bisa terjadi pada satu tataran konsep yang bekerja secara simultan pada sebuah konteks tertentu. Oleh karenanya, kelompok yang terbentuk bersifat sangat cair. Gerakannya bisa bermetamorfosis sesuai dengan perubahan dinamika motif yang terjadi di dalam kelompok tersebut. $^{73}$

Dengan menggabungkan ketiga tori social movement di atas, maka munculnya fenomena Islamisme yang terlibat aksi kekerasan tidak terlepas dari eksistensi konsep, ideologi, serta kesadaran bersama yang bersinergi dengan problem psikologis dari para tokoh pelopornya, pengikutnya, maupun masyarakat secara keseluruhan.

\section{Penutup}

Publikasi besar-besaran seputar "terorisme Islam" bisa saja disangsikan dengan argumen bahwa tidak ada media yang netral dan lepas dari pengaruh serta kepentingan pihak-pihak tertentu. Kesangsian lain, misalya, juga muncul ketika label "terorisme"

\footnotetext{
70 Niel Smelser, Theory of Collective Behavior (New York: Free Press, 1963); R. Turner dan L. Killian, Collective Behavior (Englewood Cliffs, NJ: Prentice Hall, 1987).

${ }^{71}$ Gustave Le Bon, The Crowd: A Study of the Popular Mind (New York: Viking, 1960).

${ }^{72}$ Charles Tilly, From Mobilization to Revolution (London: Addison-Wesley,1978); dan Meyer Zald dan D. McCarthy (eds.), Social Movements in an Organizational Society (New Brunswick, NJ: Transaction, 1987).

73 Bayat, "Islamism and Social Movement Theory", 903-905.
} 
dipertanyakan secara ontologis. Satu pihak bisa saja menyebut sebuah entitas individual maupun kolektif sebagai teroris, tetapi pihak lain mungkin memandangnya sebagai pahlawan pejuang kemerdekaan. Figur seperti Robin Hood, misalnya, sangat tepat untuk menggambarkan pameo "one man's terrorist is another man's freedom fighter". Tetapi, walau bagaimanapun dalam konteks kelompok teroris Muslim, elemen-elemen mendasar memang teridentifikasi dengan nyata. Eksistensi grup, tujuan politis yang hendak dicapai, aksi yang menimbulkan suasana teror, serta doktrin yang melatarbelakanginya begitu tampak kasat mata. Sehingga akan menjadi naif jika fakta-fakta yang ada kemudian dijadikan alibi untuk menegasikan ancaman yang sangat potensial ditimbulkan oleh kelompok-kelompok tersebut.

Dari tujuh kelompok teroris Muslim yang paling banyak disebut, enam di antaranya yaitu Al Qaeda, Taliban, Abu Sayyaf, alShabaab, Boko Haram, dan ISIS adalah berlatar belakang Muslim Sunnī yang berideologi Wahhabisme, lebih spesifiknya adalah Salafí-Jihādī. Keenam kelompok tersebut menjalin kerjasama dan berafiliasi dengan begitu kuat, di mana Al Qaeda sebagai poros patronnya. Hizbullah adalah satu-satunya organisasi yang berlatarbelakang Muslim Shī'ah dan menjadi klien dari kekuasaan wilayyat alfaqih di mana pemerintah Republik Islam Iran sebagai patronnya. Poros Al Qaeda bagi sebagian pihak dipandang sebagai 'pejuang' yang merepresentasikan perlawanan terhadap dominasi, hegemoni, dan kesewenang-wenangan Barat yang menjajah dunia Muslim. Hizbullah pun digadang-gadang sebagai penghadang dominasi Israel di wilayah Timur Tengah. Simbolisme doktrin Islam begitu intens mereka gunakan sebagai legitimasi atas aksi-aksi mereka, tetapi tujuan mereka tetaplah politis dan metode kekerasan yang mereka pakai cukup meneror publik dunia.

Fachry Ali, salah seorang pengamat politik yang cukup kredibel di Indonesia, pernah menyatakan bahwa memisahkan ideologi keislaman dari konsep dan aksi politik masyarakat Muslim adalah suatu hal yang nyaris tidak mungkin. Siapapun yang berusaha mengadopsi pandangan dikotomis pemisahan itu justru hanya akan menunjukkan inkapabilitas analisisnya dalam memahami konteks kultur politis Islam dan Muslim. Pendapat ini memang tampak begitu berdasar sehingga tak heran apabila ilmuwan seperti Ernest Gellner menyimpulkan bahwa Islam sudah merupakan sebuah 
'negara' (politis) dari sejak awalnya. Timbulnya konsepsi tersebut memang tak lepas dari nature ajaran Islam sendiri yang begitu komprehensif memberikan panduan bagi setiap manusia dalam menjalankan semua aspek kehidupan baik secara individual maupun kolektif di ranah spiritual maupun sosial.

Namun, pola konsepsi di atas akan sangat sulit untuk digunakan dalam rangka membedah fenomena wacana dan aksi dari elemen masyarakat Muslim yang bercorak agresif-ekstrem sehingga memunculkan labelisasi sebegitu seram seperti religiousterrorist. Semua Muslim pasti bertekad untuk berpegang pada ajarannya ketika terlibat dalam aktivitas apapun baik yang terkait dengan sosial, ekonomi, politik, bahkan budaya. Tetapi mengapa hanya sebagian kecil saja yang kemudian teridentifikasi sebagai religious terrorist?

Munculnya kelompok religious terrorists adalah sebuah fenomena Islamisme yang mengkampanyekan cita-cita terbentuknya sebuah tatanan masyarakat ideal dengan mengubah secara ekstrem sistem sosial status quo dengan sistem yang mereka yakini sebagai suci dan ilähiyah (divine). Keyakinan akan 'kesucian' ini kemudian tidak hanya berhenti pada tujuannya saja. Para kelompok religious terrorist ini kemudian mengimplementasikan sense of divine pada aksi-aksi bahkan pada sistem sosial yang coba mereka bangun. Representasi simbol keislaman kemudian menjadi begitu kental dalam bahasa dan konsep mereka. Pada titik ini, motif, aksi, dan tujuan dari setiap aksi para kelompok religious terrorist menjadi tumpang tindih antara yang ideologis dan yang politis. Motif politis, misalnya, bisa begitu tampak religius karena kentalnya simbolisasi agama. Sebaliknya, tujuan religius bisa sangat tampak politis karena langkah-langkah realisasinya membutuhkan kebijakan strategis. Jalan keluar dari labirin ketumpangtindihan perspektif ini adalah dengan memahami pola alur konstruksi yang melandasi para kelompok ini untuk mengejawantahkan motif mereka menjadi aksi.

\section{Daftar Rujukan}

Ahmed, Akbar S. Post-Modernism and Islam: Predicament and Promise. New York: Routledge, 1992.

Ali, Ayan Hirsi. "Islam is Religion of Violence", Foreign Affairs, 9 November 2015.

Anderson, Christina. "Stockholm Truck Attack Kills 4; Terrorism is Suspected", The New York Times, 7 April 2017. 
Arnett, George. "Religious Extremism Main Cause of Terrorism, According to Report", The Guardian, 18 November 2014.

Azra, Azyumardi. Pergolakan Politik Islam dari Fundamentalisme, Modernisme hingga Posmodernisme. Jakarta: Paramadina, 1996.

Bayat, Asef. "Islamism and Social Movement Theory", Third World Quarterly, Vol. 26, No. 6, 2005.

Berman, Paul. Terror and Liberalism. New York: W.W. Norton, 2004.

Binder, Leonard. Islamic Liberalism. Chicago: Chicago University Press, 1988.

Bloom, Mia. Dying to Kill: The Allure of Suicide Bombing. New York: Columbia University Press, 2005.

Bukay, David. "The Religious Foundatios of Suicide Bombings", The Middle east Quarterly, Vol. 13, No. 4, 2006.

Castells, Manuel. The Power of Identity. Oxford: Blackwell, 1997.

Chalik, Abdul. "Funadamentalisme dan Masa Depan Ideologi Politik Islam", ISLAMICA: Jumal Studi Keislaman, Vol. 9, No. 1, 2014.

Cliteur, Paul. "Why Religious Terrorism is Really Religious", Church and State, 2015. Diakses dari laman http://churchandstate.org.uk/2017/01/why-religiousterrorism-is-really-religious/, 13 April 2017.

Cordesman, Anthony H. "Broad Patterns in Global Terrorism 2014”, Center for Strategic \& International Studies, 19 Juni 2015.

Crone, Patricia. "Jihad: Idea and History", Open Democracy, 1 Mei 2007.

Dearden, Lizzie. "Sweden Terror Attack", Independent, 7 April 2017.

El Fadl, Khaled Abou. The Great Theft: Wrestling Islam from the Extremist. San Fransisco: Harper, 2005.

Esposito, John L. dan Dalia Mogahed. Who Speaks for Islam?: What a Billion of Muslims Really Think. New York: Gallup Press, 2007.

Esposito, John L. "Religion and Political Affairs: Political Challenges", SAIS Review: A Journal for International affairs, Vol. 18, No. 2, 1998.

----- Islamic Threat: Myth or Realitiy? Third Edition. New York: Oxford University Press, 1999.

Feffer, John. "Trump v. Islam”, Foreign Policy in Focus, 21 Februari 2017. 
Fine, Jonathan. "Contrasting Religious and Sekuler Terrorism", The Middle East Quarterly, Vol. 15, No. 1, 2008.

Flowers, Andrew. "Global Terrorism Declined Last Year-But not in the West", Five Thirty Eight, 30 Juni 2016.

Foucault, Michel. "An Interview with Michel Foucault", Akbtar, No. 4, 1987.

Gellner, Ernest. Post-Modernism, Reason and Religion. London and New York: Routledge, 1992.

Gibson, David. "Does religion Cause Terrorism? It's Complicated", The Huffington Post, 31 Agustus 2011. Diakses dari laman http://www.huffingtonpost.com/2011/08/ 31/religion-terrorism_n_944143.html, 17 April 2017.

Giddens, Anthony. Social Theory and Modern Society. California: Stanford University Press, 1987.

Gregg, Heather S. "Defining and Distinguishing Secular and Religious Terrorism”, Perspectives on Terrorism, Vol. 8, No. 2, 2014.

Guiora, Amos N. Freedom From Religion: Rights and National Security. Oxford: Oxford University Press, 2009.

Gunning, Jeroen dan Richard Jackson. "What's so 'Religious' about 'Religious' Terrorism", Critical Studies on Terrorrism, Vol. 4, No. 3, 2011.

Hanafi, Hassan dan M. 'Ābid al-Jābirī. Hìwār al-Mashriq wa alMaghrib. Beirut: Muassasat al-'Arabīyah, 1990.

Hanafi, Hassan. Aku Bagian dari Fundamentalisme Islam. Yogyakarta: Islamika, 2003.

Hirschkind, Charles. "What is Political Islam?", Middle East Report, No. 205, 1997.

Hoffman, Bruce. "Holy Terror: The Implications of Terrorism Motivated by a Religious Imperative", Studies in Conflict and Terrorism, Vol. 18, No. 4, 1995.

Huntington, Samuel P. "The Clash of Civilizations?", Foreign Affairs, Vol. 72, No. 3, 1993.

----. "The Age Muslim Wars", Newsweek-Special Edition, Desember 2001-Februari 2002.

Institute for Economics and Peace. Global Terrorism Index 2016. Maryland: University of Maryland, 2016. 
Jackson, Richard. 'Constructing Enemies: 'Islamic Terrorism' in Political and Academic Discourse", Government and Opposition, Vol. 42, No. 3, 2007.

Jones, James W. Blood that Cries Out from the Earth: The Psychology of

Religious Terrorism. New York: Oxford University Press, 2008.

Juergensmeyer, Mark. Teror atas Nama Tuban: Kebangkitan Global

Kekerasan Agama. Jakarta: Nizam Press \& Anima Publishing, 2002.

-----. Terror in the Mind of God: The Global Rise of Religious Violence. Berkeley: University of California Press, 2000.

Kasdi, Abdurrahman. "Fundamentalisme Islam Timur Tengah:

Akar Teologi, Kritik Wacana, dan Politisasi Agama", Tashwirul Afkar, No. 13, 2004.

Keddie. "New Religious Politics: Where, When and Why

Fundamentalism Appears?", Comparative Studies in Society and History, Vol. 40, No. 4, 1998.

Laqueur, Walter. The Age of Terrorism. Boston: Little, Brown and Company, 1987.

Le Bon, Gustav. The Crowd: A Study of the Popular Mind. New York: Viking, 1960.

Lewis, Bernard et al. The Encyclopaedia of Islam, New Edition, 1990.

Lewis, Bernard. "The Roots of Muslim Rage", Atlantic Monthly, Vol. 266, No. 3, 1990.

----. What Went Wrong. London: Phoenix, 2002.

Melucci, Alberto. Challenging Codes: Collective Action in the Information Age. Cambridge: Cambridge University Press, 1996.

Miller, Erin et al. Global Terrorism Database 2015. Maryland: START, 2016.

Omar, Manal. "Islam is the Religion of Peace", Foreign Affairs, 9 November 2015.

Pape, Robert. Dying to Win: The Strategic Logic of Suicide Terrorism. New York: Random House, 2005.

Rapoport, David C. "Fear and Trembling: Terrorism in Three Religious Traditions", American Political Science Review, Vol. 78, No. 3, 1984.

Riesebrodt, M. Pious Passion. Berkeley, CA: University of California Press, 1993. 
Rosdiawan, Ridwan, dan Atmaja, Dwi Surya. Islamic Terrorism: The Ambiguity between Accusation and Justification. Pontianak: IAIN Pontianak Press, 2016.

Sagiv, David. Islam: Otentisitas Liberalisme, terj. Yudian W. Asmin. Yogyakarta: LKiS, 1997.

Sedgwick, Mark. "Al Qaeda and the Nature of Religious Terrorism", Terrorism and Political Violence, Vol. 15, No. 4, 2004.

Silvan, Emmanuel. Radical Islam: Medieval Theology and Modern Politic. New Haven: Yale University, Press, 1990.

Smelser, Niel. Theory of Collective Behavior. New York: Free Press, 1963.

Stern, Jessica Stern. Terror in the Name of God: Why Religious Militants Kill. New York: Harper Collins, 2009.

Susanto, Edi. "Kemungkinan Munculnya Paham Islam Radikal di Pesantren", Tadris, Vol. 2, No. 1, 2007.

The White House Office of Presidential Secretary. "Executive Order: Protecting the Nation from Foreign Terrorist Entry into the United States", The White House, 27 Januari 2017.

Tilly, Charles. From Mobilization to Revolution. London: AddisonWesley,1978.

Touraine, A. The Return of the Actor. Minneapolis: University of Minnesota Press, 1988.

Tucker, David. "What is New about the New Terrorism and How Dangerous is It?", Terrorism and Political Violence, Vol. 13, No. 3, 2001.

Turner, R.H. dan Lewis M. Killian. Collective Behavior. Englewood Cliffs, NJ: Prentice Hall, 1987.

Yaqub, Ali Mustafa. "Radikalisme dan Metode Memahami Teks Agama", makalah Seminar Nasional Islam dan Terrorisme, 2006.

Zald, Meyer dan D. McCarthy. Social Movements in an Organizational Society. New Brunswick, NJ: Transaction, 1987. 